\title{
STUDI LITERATUR : KAJIAN KEUANGAN SEBAGAI PENGEMBANGAN PEMBELAJARAN KEWIRAUSAHAAN
}

\author{
${ }^{1}$ R. Susanto Hendiarto, ${ }^{2}$ Dwinto Martri Aji Buana \\ 1,2 Universitas Widyatama \\ Email: r.susanto@widyatama.ac.id
}

\begin{abstract}
ABSTRAK
Penelitian ini merupakan studi literatur kajian aspek keuangan dalam aktivitas kewirausahaan. Kajian ini bertujuan menjadi pemetaan awal dalam proses pengembangan bahan pembelajaran dan penyusunan kompetensi keuangan yang perlu dikuasai oleh seorang wirausahawan maupun calon wirausahawan dalam mengelola bisnisnya. Metode yang dilakukan adalah dengan mengumpulkan dan mengkaji literatur yang berkenaan dengan kajian keuangan untuk kemudian dapat dijadikan sebagai bahan pengembangan kurikulum pembelajaran keuangan dalam konteks kewirausahaan. Hasil studi ini menunjukkan bahwa perlunya dilakukan pemetaan bahan pembelajaran dan menyusun kajian seperangkat pengetahuan keuangan yang membangun kompetensi wirausahawan dalam mengembangkan bisnisnya. Saran dan implikasinya terhadap kajian akademis dan pembelajaran di masa yang akan datang juga dipaparkan pada bagian akhir studi ini.
\end{abstract}

Kata kunci : Keuangan, Kewirausahaan, Pembelajaran, Kompetensi, Studi Literatur

\begin{abstract}
This study is a literature study of the study of financial aspects of entrepreneurial activity. This study aims to be an early mapping in the process of developing learning materials and penyususnan financial competencies that need to be mastered by an entrepreneur or prospective entrepreneurs in managing their business. The method undertaken is to collect and review the literature relating to the financial review to then be used as material for developing the curriculum of financial learning in the context of entrepreneurship. The results of this study indicate that the need to mapping learning materials and develop a set of financial knowledge that builds entrepreneurial competence in developing its business. Suggestions and implications for future academic and learning studies are also presented at the end of this study.
\end{abstract}

Keywords: Finance, Entrepreneurship, Learning, Competency, Literature Study 


\section{PENDAHULUAN}

Istilah "kewirausahaan" saat ini menjadi kata yang banyak diperbincangkan baik dalam konteks makro atau bahkan konteks individual (Sondari, 2014). Dalam perkembangannya kekinian istilah 'kewirausahaan', 'keuangan' dan 'pembelajaran' menjadi tiga istilah yang sangat penting saat ini semenjak ketiganya menjadi penentu dalam keberlangsungan mencetak pengusaha-pengusaha baru yang profesional dalam pengelolaan bisnis.

Selama beberapa dekade belakangan ini, penelitian kewirausahaan menjadi topik yang semakin berkembang dalam ilmu ekonomi(Kerr, Nanda, \& Rhodes-Kropf, 2014).Meskipun konsep kewirausahaan memiliki sejarah panjang di sektor komersial, konsep ini telah dianut relatif baru di bidang ekonomi sosial atau sektor ketiga(Young \& Grinsfelder, 2008). Ada konsensus tentang perlunya kewirausahaan (fenomena mikro) untuk mendorong makroekonomi yang lebih besar. Namun, masih sedikit penelitian yang telah dilakukan tentang bagaimana kebijakan makroekonomi tertentu pada gilirannya berdampak pada kewirausahaan(Hartwell, 2014).

Kewirausahaan memainkan peran penting dalam penciptaan pekerjaan dan pertumbuhan ekonomi maka dari eksternalitas positif ini banyak negara telah menetapkan program dan lembaga kebijakan yang ditujukan langsung untuk mendorong kewirausahaan(Andersen, 2012). Kewirausahaan menjadi faktor penting dalam pertumbuhan dan pembangunan ekonomi di suatu negara.Sebagaimana diungkapkan pula oleh Sondari (2014)bahwa kegiatan kewirausahaan diyakini dapat menjadi alat untuk meningkatkan pertumbuhan ekonomi dan untuk menyelesaikan masalah ekonomi lainnya seperti pengangguran.

Kewirausahaan pada dasarnya adalah tentang eksperimen karena pengetahuan yang diperlukan untuk menjadi sukses tidak dapat diketahui sebelumnya atau disimpulkan dari beberapa himpunan prinsip awal (Kerr, Nanda, \& Rhodes-Kropf, 2014).Struktur keuangan merupakan pusat strategi bisnis perusahaan dan memiliki implikasi penting bagi perilaku perusahaan (Sanyal \& Mann, 2010). Kendala keuangan adalah salah satu hambatan yang paling sering dikutip kewirausahaan(Andersen, 2012).Penelitian di bidang keuangan telah tertinggal di belakang(Denis, 2004).Aktan \& Bulut (2008) telah melakukan penelitian mengenai pengaruh kewirausahaan perusahaan terhadap kinerja keuangan perusahaan dengan menghasilkan suatu panduan yang membantu pengelola usaha untuk mencapai keberhasilan perusahaan secara keuangan dan mempertahankannya di negara berkembang.

Sejalan dengan kebutuhan tersebut tidak kalah penting adalah pembelajaran mengenai kewirausahaan itu sendiri yang harus mampu berjalan dengan efektif agar tercipta wirausahawan-wirausahawan baru yang menyokong perekonomian. Menurut Sondari (2014)pendidikan kewirausahaan adalah proses menyediakan individu dengan kemampuan untuk mengenali peluang komersial dan wawasan, harga diri, pengetahuan dan keterampilan untuk mereka bertindak.

Denis (2004)mengungkapkan bahwa keuangan kewirausahaan cukup berbeda dari yang dihadapi oleh perusahaan publik sehingga membatasi penerapan teori keuangan tradisional yang setidaknya situasi kewirausahaan dicirikan oleh dua masalah mendasar yang sama yang membentuk dasar bagi banyak teori keuangan perusahaan: masalah keagenan dan asimetri informasi. Lebih lanjut ia menambahkan bahwa pembiayaan kewirausahaan berbeda dari keuangan korporasi tradisional hanya dalam arti bahwa besarnya kedua masalah ini lebih besar, sehingga membutuhkan solusi kontrak yang berbeda dari yang biasanya dihadapi di perusahaan yang lebih besar dan lebih mapan. Dengan demikian, ada kompetensi dan karakter yang khas dengan keuangan perusahaan besar sehingga ada kebutuhan perlu adanya suatu penyesuaian kembali agar relevan. 
Sondari (2014) dalam artikelnya telah menjelaskan peran pendidikan kewirausahaan dalam menciptakan niat wirausaha di kalangan siswa secara konseptual. Penelitian masa depan harus memeriksa lebih lanjut tentang jenis pendidikan kewirausahaan yang dapat berkontribusi terhadap dampak terhadap niat karir kewirausahaan. Lebih khusus lagi sebagaimana telah dipaparkan sebelumnya perlu adanya proses pembelajaran yang menumbuhkan minat dan kompetensi dalam aspek keuangan.Oleh karena itu, kita harus menemukan cara untuk menciptakan wirausahawan baru, tepat setelah atau bahkan sebelum mereka lulus (Sondari, 2014).

\section{STUDI LITERATUR}

Pada bagian ini akan dikemukakan beberapa penelitian terdahulu yang telah membahas berbagai topik berkenaan dengan keuangan pada konteks kewirausahaan. Berbagai topik yang telah terangkum diharapkan mampu menjadi gambaran dalam penyusunan kompetensi peserta didik dalam proses pembelajaran kewirausahaan.Secara historis, peneliti di bidang keuangan cenderung memandang kewirausahaan sebagai sepenuhnya terpisah dari bidang keuangan perusahaan (Denis, 2004).

\section{Struktur Keuangan Start Up}

Sedikit yang diketahui tentang struktur keuangan perusahaan startup adapun penelitian teoritis dan sebagian besar penyelidikan empiris telah berfokus pada perusahaan besar yang didirikan, yang dapat memanfaatkan berbagai sumber keuangan, seperti ekuitas saham atau kertas komersial, situasi yang sangat berbeda dari yang dihadapi perusahaan kecil(Sanyal \& Mann, 2010).

Konsisten dengan landasan teoretis berdasarkan pada spesifisitas aset, kami menemukan bahwa startup dengan aset fisik lebih banyak atau mereka yang pemiliknya memiliki bisnis lain lebih mungkin dibandingkan startup lain untuk memiliki utang eksternal dalam struktur keuangan, karena aset ini memiliki nilai likuidasi yang lebih tinggi. Di sisi lain, semua sama, startup dengan modal manusia yang lebih tinggi yang diwujudkan dalam wirausaha atau lebih banyak aset properti intelektual memiliki probabilitas penggunaan utang yang lebih rendah, konsisten dengan spesifitas aset yang lebih tinggi dan nilai agunan yang lebih rendah dari aset-aset ini.

\section{Sumber Keuangan Wirausahawan}

Perusahaan start-up adalah perusahaan yang baru didirikan atau usaha wirausaha yang berada di fase pengembangan dan riset pasar.Ketika PDB per kapita meningkat, peluang keuangan yang lebih besar untuk investasi dalam kegiatan wirausaha sedang dibuat (Čalopa, Horvat, \& Lalić, 2014).

Lebih lanjut hasilnya dipaparkan bahwa setelah bertahan dari tahap percobaan pertama, para pengusaha mendapatkan cukup keberanian untuk mencari dukungan keuangan dari sumber pendanaan lain, seperti malaikat bisnis dan investasi benih, meskipun tingkat pengembangan perusahaan dan pengalaman pengusaha tidak perlu dikaitkan dengan metode pembiayaan.

Sebagaimana pada artikel-artikel lainnya dibahas pula mengenai sumber keuangan dari usahawan. Seperti dilakukan oleh (Frid, Wyman, Gartner, \& Hechavarria, 2016) yang mengeksplorasi hubungan antara pendiri bisnis kekayaan rendah di AS dan pendanaan startup eksternal. Lalu (Fraser, Bhaumik, \& Wright, 2015)memeriksa literatur yang ada untuk 
menyoroti apa yang kita lakukan (dan tidak) ketahui tentang keuangan kewirausahaan dan hubungannya dengan pertumbuhan dan penelitian mereka menunjukkan bahwa hanya sedikit yang diketahui tentang hubungan penting antara akses ke keuangan eksternal dan pertumbuhan karena keterbatasan dalam pendekatan saat ini untuk menguji kendala keuangan. Kemudian (Bergamini, Navarro, \& Hilliard, 2017)untuk menilai penggunaan crowdfunding sebagai sumber keuangan untuk perusahaan sosial. Secara khusus, makalah ini menganalisis persepsi pengusaha sosial tentang crowdfunding, alasan yang mendorong atau menghambat penggunaannya, informasi yang berbeda yang tersedia, dan kesesuaiannya untuk perusahaan sosial. Hasilnya menunjukkan bahwa crowdfunding sebagai alat pembiayaan masih relatif tidak dikenal dan hanya sedikit digunakan oleh wirausahawan sosial, dan analisis menjelaskan mengapa demikian.

\section{Sustainability Indeks dalam Keuangan}

jumlah organisasi yang secara efektif mempengaruhi pembangunan berkelanjutan masih belum mencukupi, dan perlu meningkat secara mendesak. Ini mengilhami para peneliti di bidang kewirausahaan yang berkelanjutan untuk menyelidiki secara menyeluruh dampak keuangan dan non-keuangan positif yang mungkin telah diterapkan oleh strategi berkelanjutan(Greco \& Jong, 2017).

Mereka menyarankan bahwa indikator keuangan lainnya seperti return on equity, return on asset, cost of capital atau rasio market-tobook dapat dikaitkan dengan indeks keberlanjutan. Maka pertanyaan lain muncul: Bagaimana parameter non-keuangan dimasukkan dalam penilaian kinerja berkelanjutan? penggerak lain yang layak mendapat perhatian khusus adalah faktor finansial.

\section{Social Entrepreneur Financing Packages}

Pada artikel ini, penulis berpendapat bahwa konsepsi yang lebih luas dari pengusaha sosial adalah tepat karena perusahaan sosial tidak hanya bergantung pada kesuksesan pasar.Memang, fondasi keuangan organisasi sektor ketiga cukup bervariasi, dan variasi ini kemungkinan akan tercermin dalam paket pembiayaan untuk usaha baru, menyiratkan bahwa pengusaha sosial harus mampu menegosiasikan sektor publik dan lingkungan filantropis serta pasar.

Literatur khusus tentang kewirausahaan sosial mengidentifikasi sejumlah keterampilan penting yang diperlukan pengusaha sosial untuk menjembatani konteks publik, nonprofit, dan bisnis. Kegigihan termasuk kesabaran untuk mengatasi hambatan keuangan, peraturan, politik, dan birokrasi, terutama dalam konteks pendanaan pemerintah(Young \& Grinsfelder, 2008).

\section{Alternatif Pendanaan dan Kontrak Keuangan}

Salah satu masalah paling penting yang dihadapi perusahaan wirausaha adalah kemampuan mereka untuk mengakses modal. Karena perusahaan seperti itu biasanya belum menguntungkan dan tidak memiliki aset yang nyata, pembiayaan utang biasanya bukan merupakan pilihan. Akibatnya, pengusaha cenderung bergantung pada tiga sumber utama pembiayaan ekuitas luar: dana modal ventura, investor malaikat, dan investor perusahaan (Denis, 2004).

Situasi pembiayaan kewirausahaan dicirikan oleh dua masalah mendasar. Pertama, ada asimetri informasi besar antara pengusaha dan investor. Kedua, ada masalah moral hazard yang berpotensi serius. Setelah pengusaha mengumpulkan dana dari investor luar, 
mereka memiliki insentif untuk menyalahgunakan dana tersebut dengan membelanjakan barang-barang yang menguntungkan diri mereka secara tidak proporsional. pemerintah yang ingin mempromosikan kewiraswastaan harus menghindari kontrol modal dan sebaliknya mendorong reformasi iklim investasi lainnya (Hartwell, 2014).

\section{Financial Literacy on Venture Survival}

(Wise, 2013) melakukan investigasi terhadap dampak literasi keuangan pada kelangsungan hidup usaha baru.Penciptaan usaha baru sangat penting untuk ekonomi yang sehat. Ada banyak teori tentang mengapa begitu banyak usaha baru gagal. Satu teori seperti itu berkisar pada literasi keuangan. Dari sudut pandang praktisi, penelitian ini menyoroti tidak hanya pentingnya melek finansial dalam penciptaan usaha baru tetapi pentingnya mendorong seringnya laporan keuangan oleh pengusaha muda.

Lebih lanjut pendidikan melek finansial pengusaha yang luas sementara kelompok lain tidak akan menerima apa pun dan kemudian membandingkan dampak dari kegagalan usaha baru yang dihasilkan. Demikian pula, akan menarik untuk mengeksplorasi dampak produk wajib bulanan dari laporan keuangan tentang kegagalan usaha baru.

(Kaur, 2017)menekankan pada kebutuhan akan model perbankan berkelanjutan yang menumbuhkan sektor keuangan yang lebih inklusif, ramah lingkungan, transparan, dan komersial, serta melayani dan memadukan perempuan dengan lebih baik adalah bagian penting dari itu. Keaksaraan keuangan untuk perempuan adalah kunci, tetapi kesadaran di masyarakat juga harus memainkan peran besar dalam menjembatani kesenjangan ini dan kertas adalah langkah ke arah itu.

(OECD, 2015)menganalisis fitur-fitur utama dari berbagai teknik alternatif untuk utang langsung, termasuk "pembiayaan berbasis aset", "utang alternatif", "instrumen hibrida", dan "instrumen ekuitas"

\section{Finance on Entrepreneuship Growth}

(Somoye, 2013)mengevaluasi dampak keuangan pada pertumbuhan kewirausahaan di Nigeria menggunakan kerangka kerja pertumbuhan endogen. Peran keuangan sangat penting dalam pengembangan kewirausahaan dan Usaha Mikro, Kecil dan Menengah (UMKM). Ada cukup bukti dalam literatur yang menunjukkan bahwa pembiayaan kewirausahaan dapat menyebabkan pertumbuhan yang tinggi dalam pekerjaan, produktivitas dan akibatnya memiliki dampak positif pada pertumbuhan ekonomi.

\section{Entrepreneur's characteristics determine debt financing}

(Slavec \& Prodan, 2012) pembiayaan hutang perusahaan kecil ditentukan oleh ikatan sosial yang lemah dan kuat, self-efficacy kewirausahaan, dan pendidikan wirausaha.Kewirausahaan, proses kewirausahaan, dan wirausahawan sendiri berada di pusat diskusi kebijakan, insentif, dan riset akademis mendalam.

(Andersen, 2012) Jika kendala keuangan mengikat, rumah tangga dengan kekayaan rendah akan dibatasi dari memulai bisnis. Kendala semacam itu menghasilkan aktivitas kewirausahaan yang lebih sedikit dan, pada gilirannya, menurunkan pertumbuhan ekonomi. Akibatnya, inisiatif kebijakan sering berusaha untuk memudahkan akses ke pembiayaan. Kendala keuangan sering disebut sebagai penghalang utama untuk kewirausahaan.

(Sandri, 2010) Artikelnya menunjukkan bahwa perilaku pengusaha menghadapi pasar keuangan yang tidak lengkap dan investasi berisiko dapat menjelaskan mengapa percepatan pertumbuhan di negara berkembang cenderung dikaitkan dengan peningkatan akun saat ini. 
(U'rfillah \& Muflikhati, 2017) Penelitiannya bertujuan untuk menganalisis pengaruh karakteristik mahasiswa, karakteristik keluarga, karakteristik usaha, motivasi berwirausaha, manajemen waktu, dan manajemen keuangan terhadap pertumbuhan usaha dan prestasi akademik mahasiswa wirausaha.

(Sumantri, Fariyanti, \& Winandi, 2013) Selain itu, penelitian ini menemukan bahwa kinerja usaha dipengaruhi oleh karakteristik personal, kewirausahaan, lingkungan internal, dan lingkungan eksternal, di mana karakteristik personal wirausaha wanita pada industri pangan rumahan di Bogor adalah variabel yang paling penting yang mempengaruhi kinerja usaha wirausaha wanita.

\section{Financial Management}

(Rahman, Yaacob, \& Radzi, 2014) Banyak laporan menunjukkan bahwa perusahaan mikro selalu menghadapi banyak tantangan karena mereka tidak terampil dan berpengalaman bahkan dibimbing oleh banyak badan pemerintah. ada urgensi untuk memberkati cara khusus manajemen keuangan yang dapat mengarah pada keberhasilan bisnis mereka.

(Yulia, 2014) Efektivitas manajemen keuangan akan sangat ditentukan oleh tujuan bisnis yang dimiliki oleh pemula pemula dalam dokumen rencana strategis mereka.

(Hasyim \& Subur, 2014) Manajemen keuangan dalam menjalankan sebuah usaha kecil mikro adalah salah satuaspek yang cukup penting yang menentukan kesuksesan usaha. Dengan manajemen yangbaik maka akan diperoleh laba yang jelas jumlahnya, dan akan terjadi pengambilankeputusan yang tepat.

\section{Financial Decision and Entrepreneurial New Venture Creation}

(Ajagbe, Olujobi, Uduimoh, Okoye, \& Oke, 2016)menyimpulkan bahwa investasi dan keputusan keuangan memainkan peran penting yang semakin meningkat dalam pertumbuhan ekonomi dan penciptaan usaha baru yang bersifat wirausaha. Oleh karena itu, investasi dan kebijakan keuangan merupakan bagian dari resolusi operasional utama di negara-negara berkembang untuk mendukung investasi oleh perusahaan-perusahaan domestik, khususnya perusahaan-perusahaan teknologi kewirausahaan.

(Young \& Grinsfelder, 2008)Meskipun demikian, kewirausahaan sosial sekarang menjadi salah satu topik terpanas bagi pembuat kebijakan dan praktisi yang mencari solusi baru untuk masalah sosial di Amerika Serikat, Eropa, dan bagian lain dunia.

(Whetyningtyas, 2015) Penelitiannya menguji apakah kemampuan menyusun laporan keuangan dan jiwa kewirausahaan berpengaruh terhadap kinerja operasional UMKM.

(Sitorus, 2017) Informasi akuntansi sangat membantu dalam mengambil suatu keputusan. Namun banyak wirausaha yang tidak memiliki pengetahuan akuntansi dan diantara mereka ada yang belum memahami pentingnya pencatatan dan pembukuan bagi kelangsungan usaha.

\section{METODOLOGI}

Penelitian ini menggunakan metode studi literatur mengenai topik keuangan dari berbagai sumber yang khususnya berkaitan dengan keuangan dalam kewirausahaan yang khas dibandingkan dengan keuangan pada perusahaan besar. 


\section{PENUTUP}

Hasil studi ini menunjukkan bahwa perlunya dilakukan pemetaan bahan pembelajaran dan menyusun kajian seperangkat pengetahuan keuangan yang membangun kompetensi wirausahawan dalam mengembangkan bisnisnya. Saran dan implikasinya terhadap kajian akademis dan pembelajaran adalah perlu adanya upaya penyusunan secara lebih sistematis berkenaan dengan kurikulum keuangan dalam kewirausahaan agar dapat membekali peserta didik menghadapi tantangan kewirausahaan yang semakin kompleks dan menuntut kreatifitas dalam pemecahan masalah berdasarkan kompetensi yang dimilikinya.

\section{DAFTAR PUSTAKA}

\section{Jurnal}

Ajagbe, M. A., Olujobi, J. O., Uduimoh, A. A., Okoye, L. U., \& Oke, A. O. (2016). Technology Based Entrepreneurship Financing. Lessons for Nigeria. International Journal of Academic Research in Accounting, Finance and Management Sciences, 150-163.

Aktan, B., \& Bulut, C. (2008). Financial Performance Impacts of Corporate Entrepreneurship in Emerging Markets: A Case of Turkey. European Journal of Economics, Finance and Administrative Sciences, 69-79.

Andersen, S. (2012). Ability or Finances as Constraints on Entrepreneurship? Evidence from Survival Rates in a Natural Experiment. The Review of Financial Studies, 3684-3710.

Bergamini, T. P., Navarro, C. L.-C., \& Hilliard, I. (2017). Is Crowdfundingan Appropriate Financial Model for Social Entrepreneurship? Academy of Entrepreneurship Journal , 44-57.

Čalopa, M. K., Horvat, J., \& Lalić, M. (2014). Analysis of Financing Sources for Start-Up Companies. Management, 19, 19-44.

Denis, D. J. (2004). Entrepreneurial finance: an overview of the issues and evidence. Journal of Corporate Finance, 301-326.

Fraser, S., Bhaumik, S. K., \& Wright, M. (2015). What Do We Know About Entrepreneurial Finance and Its Relationship with Growth? International Small Business Journal, 70-88.

Frid, C. J., Wyman, D. M., Gartner, B., \& Hechavarria, D. H. (2016). Low-wealth Entrepreneurs and Access to External Financing. International Journal of Entrepreneurial Behaviour \& Research, 531-555.

Greco, A., \& Jong, G. D. (2017). Sustainabel Entrepreneurship: Definitions, Themes, and Research Gap. Working Papers Series University of Groningen, 3-35.

Hartwell, C. A. (2014). Capital Controls and the Determinants of Entrepreneurship. Journal of Economics and Finance, 434-457. 
Hasyim, M., \& Subur, R. S. (2014). Pelaatihan Manajemen Keuangan pada Pelaku Usaha Toko Kelontong Dusun Puluhan, Desa Banyusidi, Pakis, Magelang, Jawa Tengah. Jurnal Inovasi dan Kewirausahaan, 134-140.

Kaur, G. (2017). Financial Inclusion of Women Entrepreneurs in India. International Journal of Engineering Development and Research, 1529-1539.

Kerr, W. R., Nanda, R., \& Rhodes-Kropf, M. (2014). Entrepreneurship as Experimentation. Journal of Economic Perspectives, 25-48.

OECD. (2015). New Approaches to SME and Entrepreneurship Financing: Broadening the Range of Instruments. 1-119.

Rahman, N. A., Yaacob, Z., \& Radzi, R. M. (2014). Determinants of Successful Financial Management among Micro Entrepreneur in Malaysia. Journal of Asian Scientific Research, 631-639.

Sandri, D. (2010). Growth and Capital Flows with Risky Entrepreneurship. IMF Working Paper, 1-26.

Sanyal, P., \& Mann, C. L. (2010). The Financial Structure of Startup Firms: The Role of Assets, Information, and Entrepreneur Characteristics. Working Papers. Federal Reserve Bank of Boston, 1-29.

Sitorus, S. D. (2017). Pengaruh Latar Belakang Pendidikan dan Pengetahuan tentang Akuntansi terhadap Penggunaan Sistem Informasi Akuntansi pada Pedagang di Wilayah Kelurahan Helvetia Tengah Medan. At-Tawassuth, 413-436.

Slavec, A., \& Prodan, I. (2012). The influence of entrepreneur's characteristics on small manufacturing firm debt financing. Journal for East European Management Studies, 104-130.

Somoye, R. O. (2013). The Impact of Finance on Entrepreneurship Growth in Nigeria: A Cointegration Framework. ACRN Journal of Entrepreneurship Perspectives, 21-45.

Sondari, M. C. (2014). Is Entrepreneurship Education Really Needed ? : Examining the Antecedent of Entrepreneurial Career Intention. Procedia - Social and Behavioral Sciences, 44-53.

Sumantri, B., Fariyanti, A., \& Winandi, R. (2013). Faktor-Faktor yang Berpengaruh terhadap Kinerja Usaha Wirausaha Wanita: Suatu Studi pada Industri Pangan Rumahan di Bogor. Jurnal Manajemen Teknologi, 252-277.

U'rfillah, U., \& Muflikhati, I. (2017). Motivasi Berwirausaha, Manajemen Waktu, Manajemen Keuangan, dan Prestasi Akademik pada Mahasiswa Wirausaha. Jur. IIm. Kel. \& Kons., $71-82$.

Whetyningtyas, A. (2015). Analisis Pengaruh Kemampuan Menyusun Lapporan Keuangan dan Jiwa Kewirausahaan terhadap Kinerja Operasional UMKM (Studi Empiris di Klaster Bordir dan Konveksi Desa Padurenan, Kecamatan Gebog, Kabupaten Kudus). 
Oikos: Jurnal Kajian Pendidikan Ekonomi dan IImu Ekonomi, ISSN Online: 2549-2284 Volume II Nomor 2, Juli 2018

PROSIDING SEMINAR NASIONAL \& CALL FOR PAPERS 2015: Optimalisasi Peran Industri Kreatif dalam Menghadapi Masyarakat Ekonomi ASEAN, 57-68.

Wise, S. (2013). The Impact of Financial Literacy on New Venture Survival. International Journal of Business and Management, 30-39.

Young, D. R., \& Grinsfelder, M. C. (2008). Social Entrepreneuship and the Financing of Third Sector Organizations. Journal of Public Affairs Education, 543-567.

Yulia. (2014). Mengelola Keuangan bagi Wirausaha Pemula. Jurnal Khatulistiwa - Journal Of Islamic Studies , 11-27. 